Review

\title{
N-myc Downstream-Regulated Gene 2 (NDRG2) Function as a Positive Regulator of Apoptosis: A New Insight into NDRG2 as a Tumor Suppressor
}

\author{
Gayeon Kim ${ }^{1,+}$, Seyeon Lim $^{1,+}$ and Kwang Dong Kim ${ }^{1,2,3, * \mathbb{C}}$ \\ 1 Division of Applied Life Science, Gyeongsang National University, Jinju 52828, Korea; \\ kimga705@gnu.ac.kr (G.K.); yeon21@gnu.ac.kr (S.L.) \\ 2 PMBBRC, Gyeongsang National University, Jinju 52828, Korea \\ 3 Division of Life Sciences, College of Natural Science, Gyeongsang National University, Jinju 52828, Korea \\ * Correspondence: kdkim88@gnu.ac.kr; Tel.: +82-55-772-1365; Fax: +82-55-772-1359 \\ + These authors contributed equally to this work.
}

check for

updates

Citation: Kim, G.; Lim, S.; Kim, K.D. $\mathrm{N}$-myc Downstream-Regulated Gene 2 (NDRG2) Function as a Positive Regulator of Apoptosis: A New Insight into NDRG2 as a Tumor Suppressor. Cells 2021, 10, 2649. https: / /doi.org/10.3390/ cells10102649

Academic Editor: Edward V. Prochownik

Received: 25 August 2021 Accepted: 30 September 2021 Published: 4 October 2021

Publisher's Note: MDPI stays neutral with regard to jurisdictional claims in published maps and institutional affiliations.

Copyright: (C) 2021 by the authors. Licensee MDPI, Basel, Switzerland. This article is an open access article distributed under the terms and conditions of the Creative Commons Attribution (CC BY) license (https:// creativecommons.org/licenses/by/ $4.0 /)$.

\begin{abstract}
N-myc downstream-regulated gene 2 (NDRG2) is a tumor suppressor gene that increases tumor sensitivity to anticancer drugs, slows tumor progression, and inhibits metastasis. NDRG2 is suppressed in various aggressive tumor positions, whereas NDRG2 expression is associated with patient prognosis, such as an improved survival rate. In this review, we summarize the tumor suppressor mechanism of NDRG2 and provide information on the function of NDRG2 concerning the susceptibility of cells to apoptosis. NDRG2 increases the susceptibility to apoptosis in various physiological environments of cells, such as development, hypoxia, nutrient deprivation, and cancer drug treatment. Although the molecular and cell biological mechanisms of NDRG2 have not been fully elucidated, we provide information on the mechanisms of NDRG2 in relation to apoptosis in various environments. This review can assist the design of research regarding NDRG2 function and suggests the potential of NDRG2 as a molecular target for cancer patients.
\end{abstract}

Keywords: N-myc downstream-regulated gene 2; tumor suppressor; apoptosis; molecular target for tumor therapy

\section{Introduction}

The N-myc downstream-regulated gene (NDRG) family consists of NDRG1, NDRG2, NDRG3, and NDRG4. The proteins in this family are characterized by a sterase/lipase/ thioesterase active site serine and an $\alpha / \beta$ hydrase fold of about 20 amino acids; however, they do not exhibit enzyme activity [1-3]. Among the family members, NDRG2 has been well studied regarding its structure and expression profiles in tissues [4]. As a tumor suppressor or stress response gene, NDRG2 is involved in the anti-metastasis and antiproliferation of tumor cells [5-7], and is implicated in responses to stress responses, which involve hormones, ions, body fluid metabolism [8-10], hypoxia, and lipotoxicity [11,12]. Notably, genome deletion or promoter methylation (or both) of the NDRG2 gene increases tumorigenesis by inhibiting NDRG2 expression in various tumors [13-15]. Furthermore, the expression of NDRG2 is closely related to tumor prognosis $[6,16,17]$, which is associated with cancer metastasis inhibition and therapeutic outcome. The results of the treatment of tumors through radiation or drug therapy (or both) are closely related to the induction of apoptosis in tumor cells. In this review, we summarize the antitumor function of NDRG2 as a tumor suppressor gene and the function of NDRG2 in relation to apoptosis in various physiological environments as a prognostic tumor marker.

\section{NDRG2 Functions as a Tumor Suppressor}

Downregulated NDRG2 expression is closely related to poor prognoses, such as a reduction in overall survival and disease-free survival rates in tumor patients [6]. NDRG2 
regulates the pathological processes associated with tumor aggressiveness, such as proliferation and invasion/epithelial-mesenchymal transition (EMT) in various tumors. NDRG2 regulates intracellular signals by inhibiting c-Jun phosphorylation and cyclin D expression, thus inhibiting cell proliferation [16]. NDRG2 overexpression was shown to decrease intracellular $\beta$-catenin levels and TCF/LEF activity by activating glycogen synthase kinase $3 \beta$ (GSK-3 $\beta$ ) in a colorectal carcinoma cell line, SW620. The inhibition of TCF / $\beta$-catenin activity by NDRG2 suppresses tumor metastasis [18]. The MMP (matrix metalloproteinase) family contributes to the degradation of the extracellular matrix in tumor progression and metastasis [19-21]. Furthermore, NDRG2 expression was shown to be associated with MMP downregulation in clear cell renal cell carcinoma (CCRCC) and hepatocellular carcinoma (HCC) [22,23]. Additionally, MMP expression is regulated through mechanisms such as ERK1/2 inhibition, NFKB signaling regulation, and TGF $\beta$ signaling inhibition by NDRG2 overexpression [17,22,24-26]. NDRG2 has a role as a PP2A recruiter, inhibiting NFKB signaling by inducing NFKB-inducing kinase (NIK) dephosphorylation [27]. NDRG2 was shown to suppress the TGF- $\beta 1$-mediated induction of MMP through the regulation of integrin $\alpha 3$ expression in hepatocarcinoma and integrin $\alpha 6$ expression in metastatic murine breast cancer cells (4T1), thereby suppressing the activation of latent extracellular TGF- $\beta[17,26]$.

Various stimuli, such as the IL-6 family, EGF, and IGF, activate Janu kinase/signal transducer and activator of transcription (JAK/STAT) signaling [28]. Signal transducer and activator of transcription 3 (STAT3) plays a role in cell proliferation, survival, and invasion/metastasis as a tumorigenic player [29-31]. NDRG2 expression suppresses Snail expression at the transcriptional level and epithelial-mesenchymal transition (EMT) by inhibiting STAT3 [32]. Snail is a zinc-finger transcription regulator that inhibits E-cadherin expression and initiates EMT [33]. The silencing of suppressors of cytokine signaling (SOCS-1) contributes to the preferential activation of STAT3 by the JAK pathway [34]. The overexpression of NDRG2 in MBA-MB231 breast cancer cells increases SOCS-1 expression, and the JAK/STAT3 pathway is negatively regulated by SOCS-1 [35]. Although there are reports on the NDRG2-mediated regulation of signal transduction and EMT-inducing transcription factor, the exact molecular mechanism has not been fully elucidated.

The Warburg effect indicates that cancer cells prefer metabolism through glycolysis over the much more efficient oxidative phosphorylation pathway that is favored by most other cells. Therefore, increased glucose consumption is required, as glucose is a carbon source for anabolic processes to support cell proliferation. An increase in glucose transporters (GLUTs) is required to enable large amounts of glucose to be taken up in tumors [36-39]. GLUT-1 promotes glucose transport across the plasma membrane of mammalian cells, and GLUT-1 overexpression is a prognostic biomarker of cancer $[40,41]$ and can be a potential target, as it has been shown to regulate cancer in several reports [42-44]. NDRG2 expression was shown to inhibit glucose uptake by promoting the degradation of GLUT1 protein in breast cancer cells [8]. Catalytic enzymes, such as hexokinase 2 (HK2), pyruvate kinase M2 (PKM2), lactate dehydrogenase A (LDHA), and GLUT-1, are markedly inhibited by NDRG2 expression in colorectal cancer cells and patients [45]. Altogether, NDRG2 is an important prognostic marker that controls various cellular physiological pathways involved in tumor aggressiveness (Figure 1). 


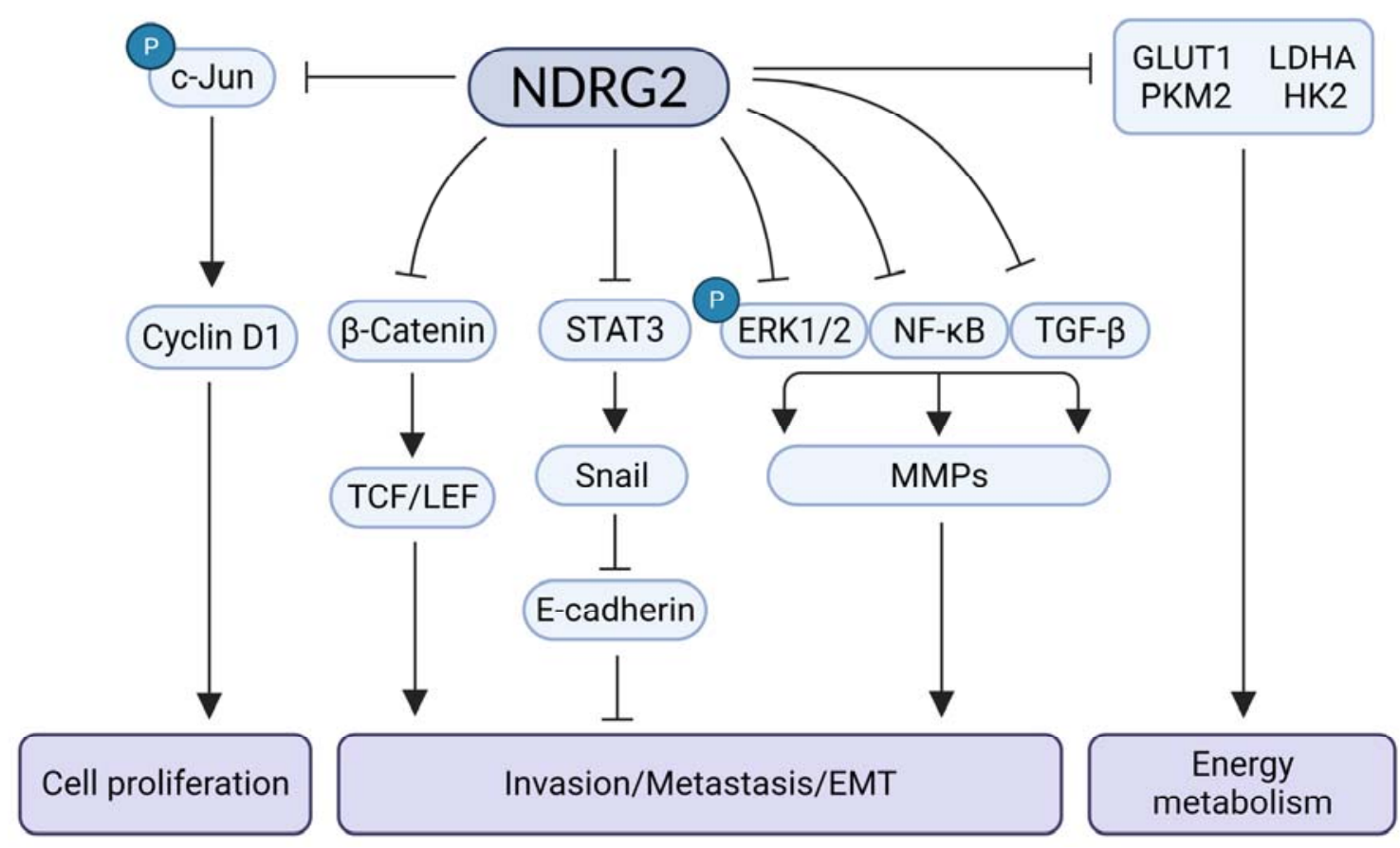

Figure 1. Overview of NDRG2-mediated antitumor activity. GLUT, glucose transporter; LDHA, lactate dehydrogenase A; PKM2, pyruvate kinase M2; HK2, hexokinase 2; TCF/LEF, T-cell factor/lymphoid enhancer factor; STAT3, signal transducer and activator of transcription 3; ERK1/2, extracellular signal-regulated protein kinase; NFKB, nuclear factor kappa-light-chain-enhancer of activated B cells; TGF- $\beta$, transforming Growth Factor- $\beta$; MMP, matrix metalloproteinase; EMT, epithelial-mesenchymal transition.

\section{Proapoptotic Function of NDRG2}

\subsection{Spermatogenesis and NDRG2}

Leydig cells are the main constituent of interstitial cells and produce testosterone for spermatogenesis in the testes [46]. Abnormalities of Leydig cells are prevalent in infertility diseases, and apoptosis of the cells was found in the testes of patients with maturation arrest and Sertoli cell-only syndrome (SCO) [47]. In Sprague-Dawley rats and the TM3 Leydig cell line treated with Leydig-cell-specific toxicant ethane dimethanesulfonate (EDS), NDRG2 is upregulated and translocated into the nucleus from the cytoplasm under apoptotic stimulation. The knockdown of NDRG2 induced increased proliferation and decreased apoptotic TM3 cells [48]. In the pathogenic process of cryptorchidism, p53 and proapoptotic proteins were upregulated in germ cells undergoing apoptosis, and p53 was associated with spontaneous germ cell death in the first wave of spermatogenesis [49,50]. NDRG2 and $\mathrm{p} 53$ expression was significantly upregulated in germ cells purified seven days after surgery, the upregulated expression of NDRG2 was associated with testicular germ cell apoptosis in cryptorchid testes [51]. Additionally, NDRG2 is a novel p53-inducible target involved in the p53-mediated apoptosis pathway [52]. Therefore, this suggests that NDRG2 is a novel gene involved in Leydig cell apoptosis and male fertility associated with p53 function.

\section{2. $p 53$-Mediated Apoptosis and NDRG2}

As a tumor suppressor, p53 is the most important factor that maintains genomic integrity [53], and it is widely accepted that p53-mediated apoptosis is essential for the tumor-suppressive activity of p53 [54,55]. NDRG2 is a new target gene that is regulated by p53. The level of mRNA and protein in NDRG2 is upregulated in a p53-dependent manner, and the silencing of NDRG2 attenuates p53-mediated apoptosis [52]. Furthermore, the overexpression of NDRG2 and p53 was shown to enhance the apoptosis of Huh7 cells (mutant p53) after Adriamycin-based chemotherapy and suppress the expression of the 
ERCC6 gene [56], which is involved in a sub-pathway of nucleotide excision repair and is associated with cancer drug resistance $[57,58]$. The expression of murine double minute gene 2 (MDM2) induces ubiquitination and mediates the degradation of wild-type p53, which promotes tumorigenesis [59]. The combination of MDM2 knockdown and NDRG2 overexpression inhibits cancer cell proliferation and induces apoptosis in vitro and in the xeno-transplantation model [60]. Additionally, NDRG2 is a substrate of novel deathassociated protein kinase 1 (DAPK1), which promotes apoptosis induced by various stimuli and plays a role in tumor suppression [61-64]. The DAPK1-mediated phosphorylation of NDRG2 Ser350 promotes caspase-dependent apoptosis in neuronal cells treated with ceramide. DAPK1 increases p53 expression and p53 increases DAPK1 expression, suggesting a positive feedback regulation between DAPK1 and p53 [65,66]. DAPK1/p53/NDRG2 may play a role in apoptosis induced by various stimuli in several cell types (Figure 2). Altogether, NDRG2 plays a role in inducing p53-mediated apoptosis in tumor cells.

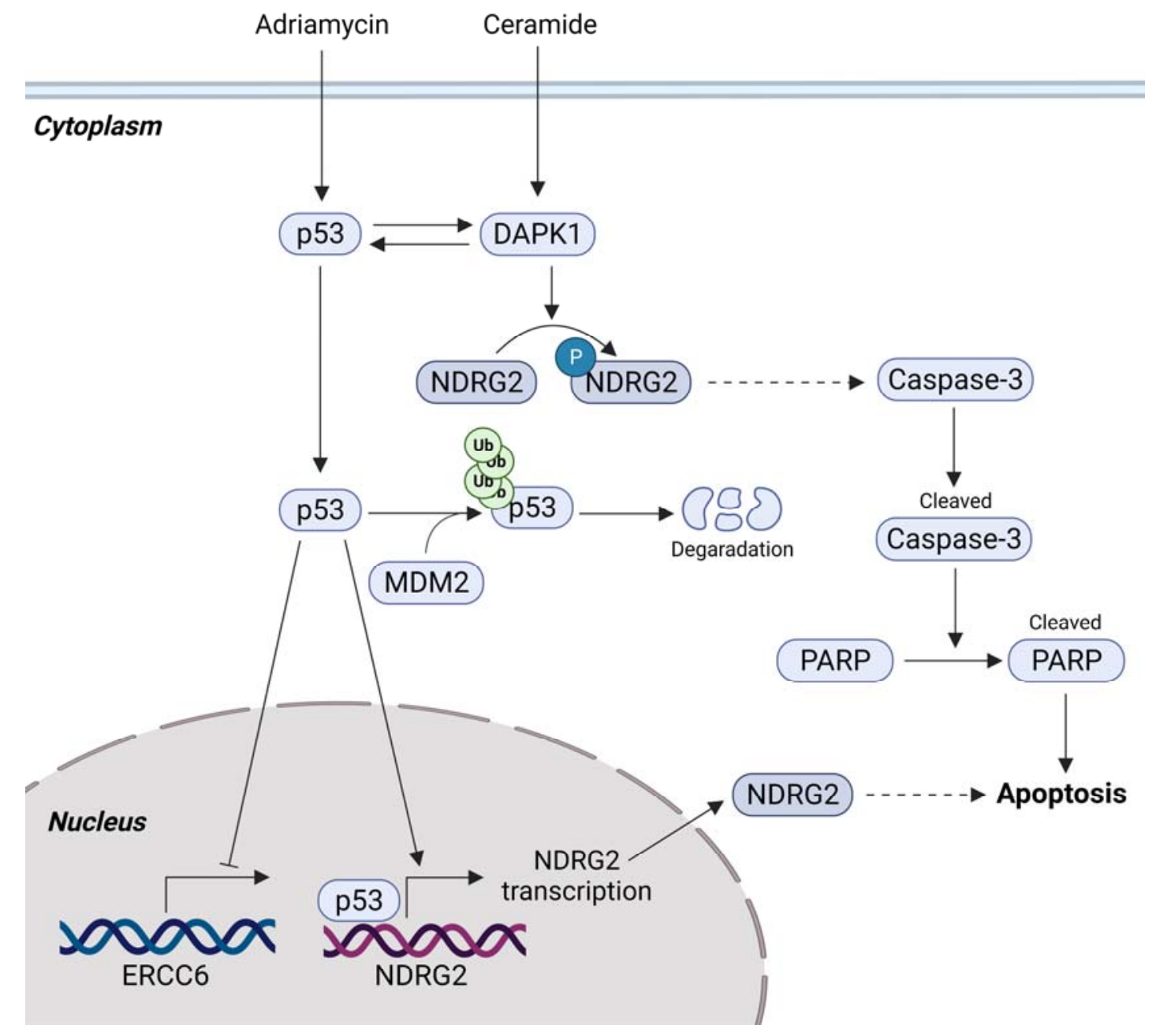

Figure 2. NDRG2 associated with p53-mediated apoptosis. NDRG2 is a novel p53-inducible target gene that is involved in p53-mediated apoptosis pathway. Unknown pathway (dotted arrow); DAPK1, death associated protein kinase 1; MDM2, mouse double minute 2; ERCC6, ERCC Repair 6; PARP, Poly (ADP-ribose) polymerase.

\subsection{Sensitivity to Anticancer Drugs and NDRG2}

The outcome of drug treatment for patients with cancer is an important factor that directly affects prognoses, such as survival and remission rates. There are several reports that show that NDRG2 contributes to drug sensitivity in tumor cells. NDRG2 overexpression enhanced the sensitivity of breast [67] and lung cancer cells [52] to Adriamycin in a 
p53-dependent manner. In the breast cancer cell line, NDRG2 overexpression prolonged the half-life of Bad and promoted the formation of the Bad/p53 complex in the mitochondria by inhibiting p53 from translocating into the nucleus [67]. NDRG2 also enhanced the sensitivity of an ovarian cancer cell line, SKOV-3, to pazopanib by activating the SK1/JNK1 signaling pathway [68]. NDRG2 enhanced the sensitivity to cisplatin and $\mathrm{As}_{2} \mathrm{O}_{3}$ in a p53 loss-of-function mutant myeloma cell line, U937 [69,70]. The degradation of Mcl-1 and the increase in Bak was mediated by JNK activation [71] and an increase in phospho-eIF2 $\alpha$, respectively, in NDRG2-overexpressed U937 cells after cisplatin treatment [69]. JNK activation and phospho-eIF2 $\alpha$ were induced by PKR activation $[72,73]$ through increased reactive oxygen species (ROS) mediated by NOX5 [74,75] induction in NDRG2-overexpressed U937. Furthermore, U937 cells were shown to be resistant to $\mathrm{As}_{2} \mathrm{O}_{3}$, a cancer drug used for myeloma [76]. NDRG2 overexpression induced Mcl-1 degradation and apoptosis through GSK3 $\beta$ activation. NDRG2 mediated the interaction between GSK3 $\beta$ and protein phosphatase 2A (PP2A), inducing the dephosphorylation of GSK3 $\beta$ at S9 by PP2A [70]. The interaction between NDRG2 and PP2A also activated PTEN, inhibiting AKT activation associated with cell survival and tumorigenesis $[15,77]$. Therefore, this shows that NDRG2 expression regulates pro/antiapoptotic protein levels, increasing the sensitivity of tumor cells to anticancer drugs (Figure 3).

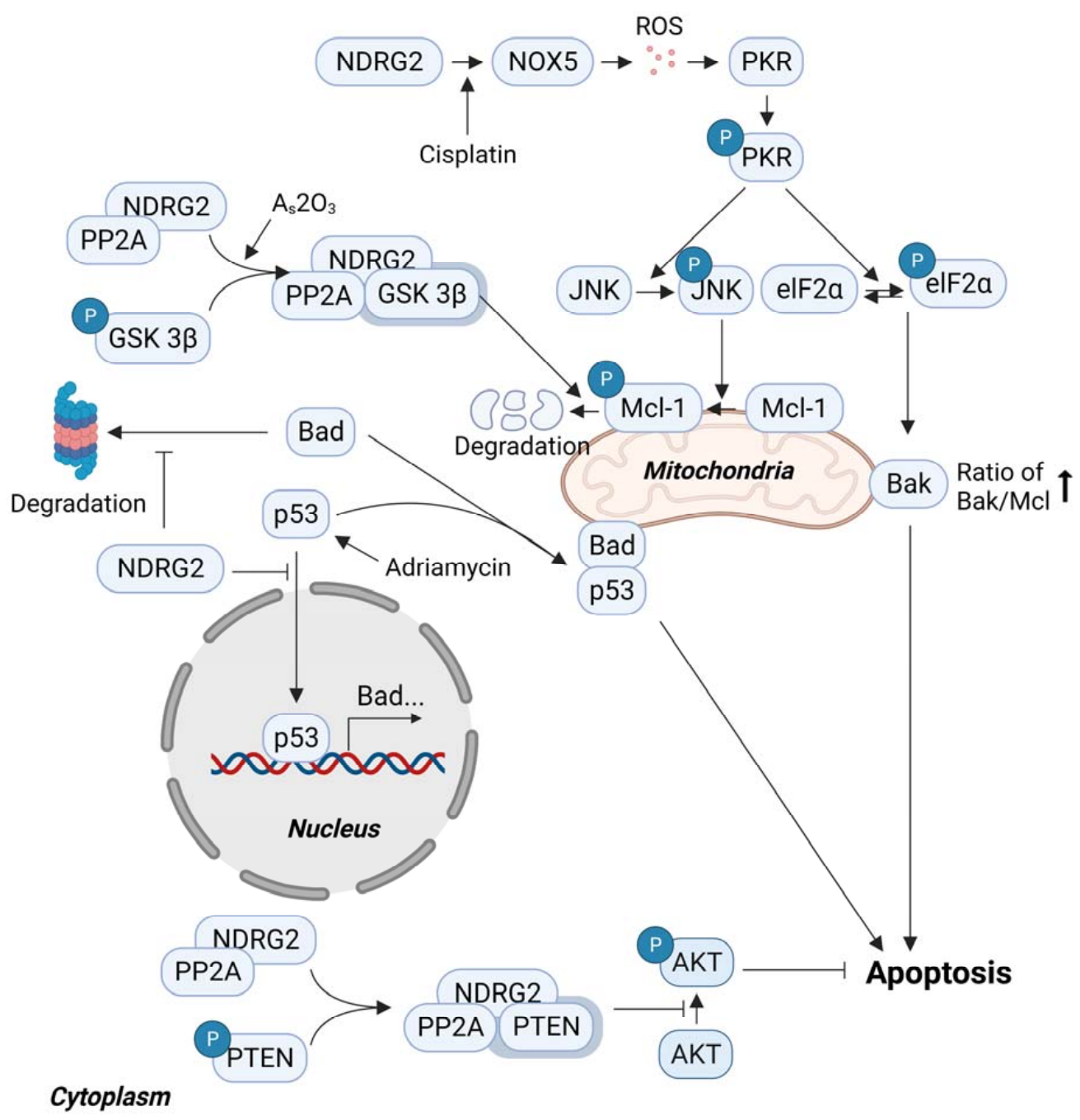

Figure 3. NDRG2 induces apoptosis to improve drug sensitivity in tumor cells. As an adaptor protein, NDRG2 increases the sensitivity of cells to apoptosis by mediating the PP2A-PTEN interaction and the PP2A-GSK3 $\beta$ interaction. NOX5 upregulation by NDRG2 enhances cisplatin-mediated apoptosis through ROS production. PP2A, protein phosphatase 2A; Mcl-1, myeloid leukemia cell differentiation protein-1; eIF, eukaryotic initiation factor; PKR, protein kinase R; NOX, NADPH oxidase; PTEN, phosphatase and tensin homolog). 


\subsection{Metabolic Stress and NDRG2}

Oxygen is an essential factor that allows energy metabolism to perform biogenesis in cells, and hypoxia, the limitation of oxygen supply, is a crucial physiological stressor associated with various pathologies, such as stroke, infarction [78,79], brain injury [80], and tumorigenesis [81]. In tumor tissue, the rapid proliferation of tumor cells exceeds the vascular structures that surround the tumor and supply oxygen and nutrients to tumor cells. Hypoxia induces intratumoral oxygen gradients, contributing to tumor plasticity and promoting more aggressive and metastatic phenotypes of tumor cells $[82,83]$. Hypoxiainducible factors (HIFs) are hypoxia-inducible transcription factors that contribute to the pathogenesis of pulmonary arterial hypertension, systemic hypertension, hereditary erythrocytosis, and cancer [84-86]. In a human lung cancer cell line, A594, mRNA and protein of NDRG2 were upregulated under hypoxic conditions [87]. HIF-1 directly bound to the putative hypoxia response element motif, from -188 to $-183 \mathrm{bp}$, in the NDRG2 promoter. Silencing NDRG2 expression reduced apoptosis under hypoxic conditions, and miRNAs were shown to regulate NDRG2 expression under hypoxic conditions. In H9c2 cells modeling myocardial injury in vitro, hypoxia conditions inhibited miR-486 expression, which induced the upregulation of NDRG2 and increased apoptosis. NDRG2 is a target of miR-486, and silencing NDRG2 expression reduced the apoptosis of $\mathrm{H} 9 \mathrm{c} 2$ cells under hypoxic conditions [88]. Additionally, other hypoxia response miRNAs, Mir-301a and $\mathrm{miR}-301 \mathrm{~b}$, were upregulated in LNCaP prostate cancer cells under hypoxic conditions, and decreased NDRG2 expression by directly targeting $3^{\prime}$ UTR of NDRG2. High levels of mir-301a and mir301b expression and silencing NDRG2 expression led to increased autophagy and reduced apoptosis $[89,90]$. Oxygen-glucose deprivation (OGD) can be used to study the effects of ischemia in cultured brain capillary endothelial cells. NDRG2 expression in C6 glioma cells was increased and translocated from cytosol to the nucleus, and increased the Bax/Bcl-2 ratio and apoptosis after OGD stress in a p53-dependent manner [91]. NDRG2 overexpression enhanced the proapoptotic effect and attenuated AMPK phosphorylation induced by glucose deprivation in a breast cancer cell, MDAMB231 [92]. Under energy stress conditions, AMPK was shown to promote autophagy by reducing mTOR activation and inducing ULK1 activation through the phosphorylation of Ser 317 and Ser 777 [93-95]. There is a mutual inhibition relationship between autophagy and apoptosis; therefore, the inhibition of autophagy may induce apoptosis [96]. Although the NDRG2 function associated with autophagy has not been well studied, downregulated NDRG2 expression contributed to increased autophagy and reduced apoptosis in prostate cancer cells under hypoxic conditions $[89,90]$. Overall, NDRG2 contributes to the induction of apoptosis in various tissue cells under metabolic stress, such as oxygen deprivation or glucose deprivation (or both) (Figure 4). 


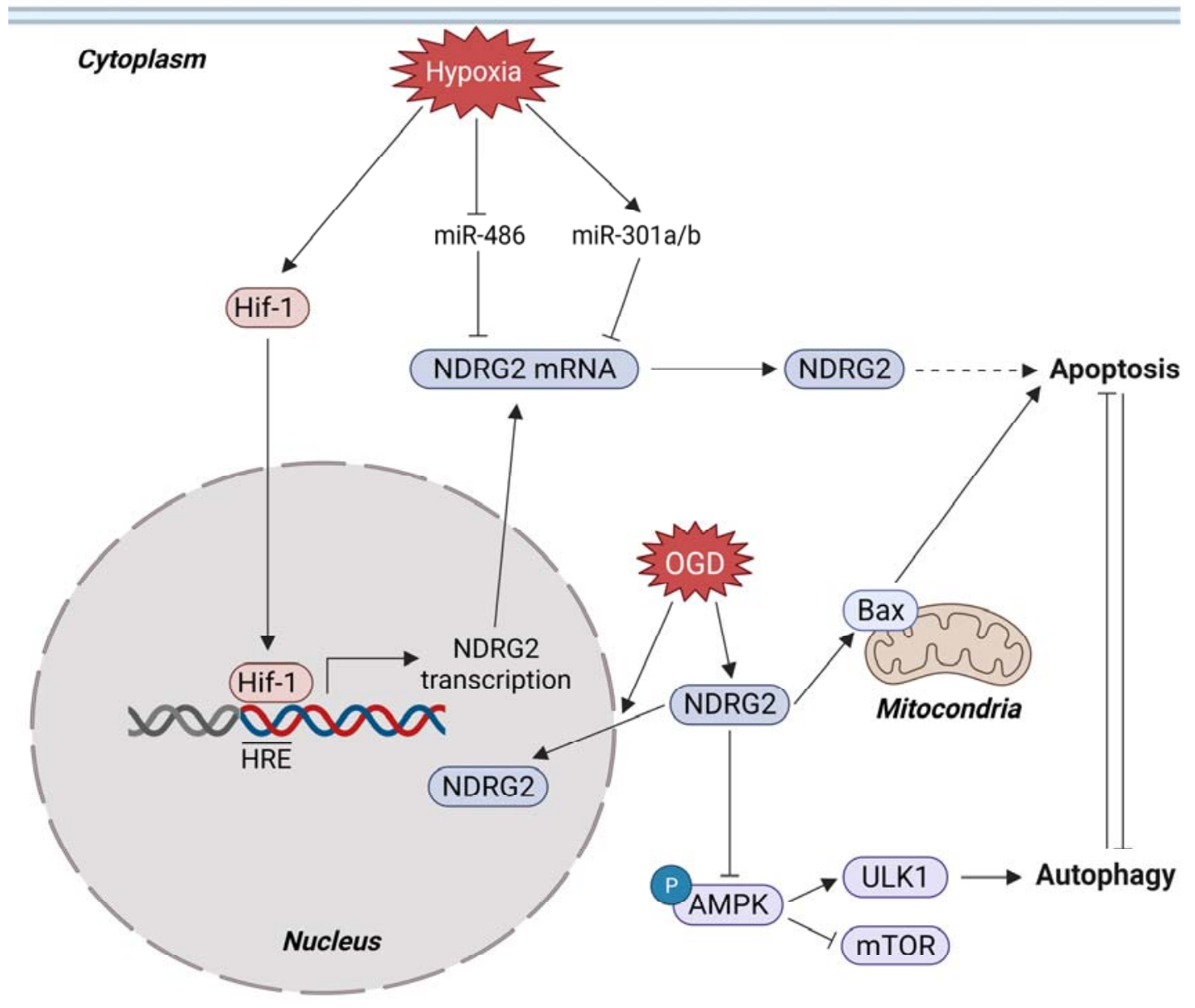

Figure 4. NDRG2 functions in the sensitivity of tumor cells to metabolic stresses (red), hypoxia, glucose deprivation, or both (OGD, oxygen-glucose deprivation). Hif-1, hypoxia inducible factor-1; AMPK, AMP-activated protein kinase; ULK1, Unc-51 like autophagy activating kinase 1 ; mTOR, mammalian target of rapamycin.

\section{Conclusions/Outlook}

The expression of NDRG2 may be unique to different patients and is inversely associated with the clinical stage, disease-free survival rate, overall survival rate, or both rates. The expression of NDRG2 as a tumor-suppressive and stress-responsive gene could be negatively or positively regulated through the epigenetic regulation of the NDRG2 promoter, miRNA, c-Myc, p53, and HIF-1 $\alpha$ under several physiological conditions. Overexpressed NDRG2 inhibits tumor cell proliferation and invasion/metastasis and sensitizes tumor cells to anticancer therapy by enhancing apoptosis (Figure 5).

The resistance of tumor cells to apoptosis can promote aggressiveness and poor prognosis in various physiological conditions, such as hypoxia, nutrient deprivation, and anticancer drug treatment. Therefore, the identification of strategies to overcome the resistance of tumor cells to apoptosis will significantly help enhance the effectiveness of tumor treatment. Furthermore, NDRG2 expression is positively correlated with apoptosis induced by metabolic stressors, such as oxygen deprivation, glucose deprivation, or both, and anticancer drug treatments. Although mechanisms that regulate NDRG2 gene expression and NDRG2-mediated improvements of tumor cell apoptosis have been presented, the molecular mechanisms of these aspects are unclear. Although its functional domain is not well known, NDRG2 has recently been reported to interact with kinases or phosphatases (or both). Its potential as an adapter protein that mediates protein-protein interactions appears to induce antitumor phenotypes in several tumor cells. In the future, the continued discovery of and functional studies on proteins that interact with NDRG2 should be conducted. It is expected that tumor treatment strategies that account for the 
expression pattern of NDRG2 or that regulate NDRG2 expression should increase the efficiency of tumor treatments.

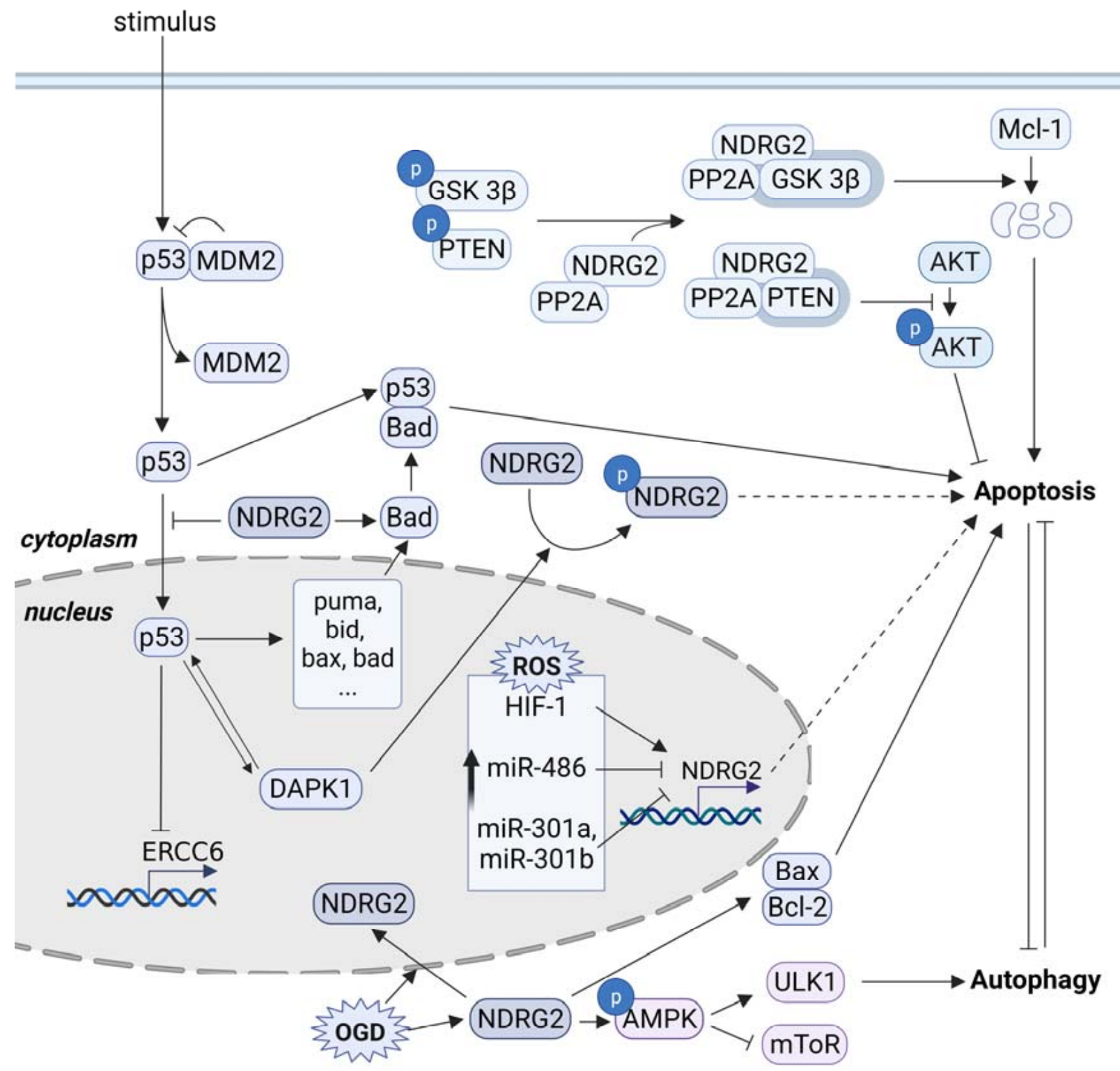

Figure 5. Overview of NDRG2 function in various stimuli-mediated apoptosis.

Author Contributions: K.D.K. drafted the manuscript outline; K.D.K., G.K., and S.L. conceived the ideas and prepared the figures. All authors have read and agreed to the published version of the manuscript.

Funding: This work was supported by the BioGreen21 Agri-Tech Innovation Program (SA00016073), the Rural Development Administration, Korea, and the National Research Foundation of Korea (NRF) grant funded by the Korea government (MSIT) (No. 2021R1A5A8029490).

Institutional Review Board Statement: Not applicable.

Informed Consent Statement: Not applicable.

Conflicts of Interest: The authors declare no conflict of interest. 


\section{References}

1. Melotte, V.; Qu, X.; Ongenaert, M.; van Criekinge, W.; de Bruine, A.P.; Baldwin, H.S.; van Engeland, M. The N-myc downstream regulated gene (NDRG) family: Diverse functions, multiple applications. FASEB J. Off. Publ. Fed. Am. Soc. Exp. Biol. 2010, 24, 4153-4166. [CrossRef] [PubMed]

2. Qu, X.; Zhai, Y.; Wei, H.; Zhang, C.; Xing, G.; Yu, Y.; He, F. Characterization and expression of three novel differentiation-related genes belong to the human NDRG gene family. Mol. Cell. Biochem. 2002, 229, 35-44. [CrossRef] [PubMed]

3. Shaw, E.; McCue, L.A.; Lawrence, C.E.; Dordick, J.S. Identification of a novel class in the alpha/beta hydrolase fold superfamily: The N-myc differentiation-related proteins. Proteins 2002, 47, 163-168. [CrossRef] [PubMed]

4. Yao, L.; Zhang, J.; Liu, X. NDRG2: A Myc-repressed gene involved in cancer and cell stress. Acta Biochim. Biophys. Sin. 2008, 40, 625-635. [CrossRef] [PubMed]

5. Chen, X.L.; Lei, L.; Hong, L.L.; Ling, Z.Q. Potential role of NDRG2 in reprogramming cancer metabolism and epithelial-tomesenchymal transition. Histol. Histopathol. 2018, 33, 655-663. [CrossRef]

6. $\mathrm{Gu}, \mathrm{A} . ; \mathrm{Xu}, \mathrm{J} . ; \mathrm{Ye}, \mathrm{J} . ; \mathrm{Zhang}$, C. Low NDRG2 expression predicts poor prognosis in solid tumors: A meta-analysis of cohort study. Medicine 2020, 99, e22678. [CrossRef] [PubMed]

7. Hu, W.; Fan, C.; Jiang, P.; Ma, Z.; Yan, X.; Di, S.; Jiang, S.; Li, T.; Cheng, Y.; Yang, Y. Emerging role of N-myc downstream-regulated gene 2 (NDRG2) in cancer. Oncotarget 2016, 7, 209-223. [CrossRef]

8. Ma, J.; Liu, W.; Guo, H.; Li, S.; Cao, W.; Du, X.; Lei, S.; Hou, W.; Xiong, L.; Yao, L.; et al. N-myc downstream-regulated gene 2 expression is associated with glucose transport and correlated with prognosis in breast carcinoma. Breast Cancer Res. BCR 2014, 16, R27. [CrossRef] [PubMed]

9. Li, Y.; Yang, J.; Li, S.; Zhang, J.; Zheng, J.; Hou, W.; Zhao, H.; Guo, Y.; Liu, X.; Dou, K.; et al. N-myc downstream-regulated gene 2, a novel estrogen-targeted gene, is involved in the regulation of $\mathrm{Na}+/ \mathrm{K}+-\mathrm{ATPase}$. J. Biol. Chem. 2011, 286, 32289-32299. [CrossRef]

10. Li, Y.; Liu, C.; Hou, W.; Ma, J.; Lin, K.; Situ, Z.; Xiong, L.; Li, S.; Yao, L. Retrograde ductal administration of the adenovirusmediated NDRG2 gene leads to improved sialaden hypofunction in estrogen-deficient rats. Mol. Ther. J. Am. Soc. Gene Ther. 2014, 22, 908-918. [CrossRef]

11. Shen, L.; Liu, X.; Hou, W.; Yang, G.; Wu, Y.; Zhang, R.; Li, X.; Che, H.; Lu, Z.; Zhang, Y.; et al. NDRG2 is highly expressed in pancreatic beta cells and involved in protection against lipotoxicity. Cell. Mol. Life Sci. CMLS 2010, 67, 1371-1381. [CrossRef] [PubMed]

12. Liu, J.; Zhang, J.; Wang, X.; Li, Y.; Chen, Y.; Li, K.; Yao, L.; Guo, G. HIF-1 and NDRG2 contribute to hypoxia-induced radioresistance of cervical cancer Hela cells. Exp. Cell Res. 2010, 316, 1985-1993. [CrossRef]

13. Liu, N.; Wang, L.; Liu, X.; Yang, Q.; Zhang, J.; Zhang, W.; Wu, Y.; Shen, L.; Zhang, Y.; Yang, A.; et al. Promoter methylation, mutation, and genomic deletion are involved in the decreased NDRG2 expression levels in several cancer cell lines. Biochem. Biophys. Res. Commun. 2007, 358, 164-169. [CrossRef] [PubMed]

14. Wei, M.; Ma, Y.; Shen, L.; Xu, Y.; Liu, L.; Bu, X.; Guo, Z.; Qin, H.; Li, Z.; Wang, Z.; et al. NDRG2 regulates adherens junction integrity to restrict colitis and tumourigenesis. EBioMedicine 2020,61, 103068. [CrossRef]

15. Nakahata, S.; Ichikawa, T.; Maneesaay, P.; Saito, Y.; Nagai, K.; Tamura, T.; Manachai, N.; Yamakawa, N.; Hamasaki, M.; Kitabayashi, I.; et al. Loss of NDRG2 expression activates PI3K-AKT signalling via PTEN phosphorylation in ATLL and other cancers. Nat. Commun. 2014, 5, 3393. [CrossRef] [PubMed]

16. Kim, Y.J.; Yoon, S.Y.; Kim, J.T.; Choi, S.C.; Lim, J.S.; Kim, J.H.; Song, E.Y.; Lee, H.G.; Choi, I.; Kim, J.W. NDRG2 suppresses cell proliferation through down-regulation of AP-1 activity in human colon carcinoma cells. Int. J. Cancer 2009, 124, 7-15. [CrossRef]

17. Oh, S.S.; Kim, D.; Kim, D.H.; Chang, H.H.; Sohn, K.C.; Kim, K.H.; Jung, S.H.; Lee, B.K.; Kim, J.H.; Kim, K.D. NDRG2 correlated with favorable recurrence-free survival inhibits metastasis of mouse breast cancer cells via attenuation of active TGF-beta production. Carcinogenesis 2012, 33, 1882-1888. [CrossRef]

18. Kim, Y.J.; Yoon, S.Y.; Kim, J.T.; Song, E.Y.; Lee, H.G.; Son, H.J.; Kim, S.Y.; Cho, D.; Choi, I.; Kim, J.H.; et al. NDRG2 expression decreases with tumor stages and regulates TCF/beta-catenin signaling in human colon carcinoma. Carcinogenesis 2009, 30, 598-605. [CrossRef]

19. Chandler, S.; Miller, K.M.; Clements, J.M.; Lury, J.; Corkill, D.; Anthony, D.C.; Adams, S.E.; Gearing, A.J. Matrix metalloproteinases, tumor necrosis factor and multiple sclerosis: An overview. J. Neuroimmunol. 1997, 72, 155-161. [CrossRef]

20. Wang, J.; Shi, Q.; Yuan, T.X.; Song, Q.L.; Zhang, Y.; Wei, Q.; Zhou, L.; Luo, J.; Zuo, G.; Tang, M.; et al. Matrix metalloproteinase 9 (MMP-9) in osteosarcoma: Review and meta-analysis. Clin. Chim. Acta 2014, 433, 225-231. [CrossRef]

21. Bauvois, B. New facets of matrix metalloproteinases MMP-2 and MMP-9 as cell surface transducers: Outside-in signaling and relationship to tumor progression. Biochim. Biophys. Acta 2012, 1825, 29-36. [CrossRef]

22. Guo, Y.; Ma, J.; Wu, L.; Wang, Q.; Li, X.; Zhang, Y.; Zhang, J.; Yao, L.; Liu, W. Hyperthermia-induced NDRG2 upregulation inhibits the invasion of human hepatocellular carcinoma via suppressing ERK1/2 signaling pathway. PLoS ONE 2013, 8, e61079. [CrossRef] [PubMed]

23. Ma, J.J.; Kong, L.M.; Liao, C.G.; Jiang, X.; Wang, Y.; Bao, T.Y. Suppression of MMP-9 activity by NDRG2 expression inhibits clear cell renal cell carcinoma invasion. Med. Oncol. 2012, 29, 3306-3313. [CrossRef]

24. Wang, J.; Yin, D.; Xie, C.; Zheng, T.; Liang, Y.; Hong, X.; Lu, Z.; Song, X.; Song, R.; Yang, H.; et al. The iron chelator Dp44mT inhibits hepatocellular carcinoma metastasis via N-Myc downstream-regulated gene 2 (NDRG2)/gp130/STAT3 pathway. Oncotarget 2014, 5, 8478-8491. [CrossRef] 
25. Kim, A.; Kim, M.J.; Yang, Y.; Kim, J.W.; Yeom, Y.I.; Lim, J.S. Suppression of NF-kappaB activity by NDRG2 expression attenuates the invasive potential of highly malignant tumor cells. Carcinogenesis 2009, 30, 927-936. [CrossRef] [PubMed]

26. Lee, D.C.; Kang, Y.K.; Kim, W.H.; Jang, Y.J.; Kim, D.J.; Park, I.Y.; Sohn, B.H.; Sohn, H.A.; Lee, H.G.; Lim, J.S.; et al. Functional and clinical evidence for NDRG2 as a candidate suppressor of liver cancer metastasis. Cancer Res. 2008, 68, 4210-4220. [CrossRef]

27. Ichikawa, T.; Nakahata, S.; Fujii, M.; Iha, H.; Morishita, K. Loss of NDRG2 enhanced activation of the NF-kappaB pathway by PTEN and NIK phosphorylation for ATL and other cancer development. Sci. Rep. 2015, 5, 12841. [CrossRef]

28. Jin, W. Role of JAK/STAT3 Signaling in the Regulation of Metastasis, the Transition of Cancer Stem Cells, and Chemoresistance of Cancer by Epithelial-Mesenchymal Transition. Cells 2020, 9, 217. [CrossRef] [PubMed]

29. Yu, H.; Pardoll, D.; Jove, R. STATs in cancer inflammation and immunity: A leading role for STAT3. Nat. Rev. Cancer 2009, 9, 798-809. [CrossRef]

30. Yu, H.; Lee, H.; Herrmann, A.; Buettner, R.; Jove, R. Revisiting STAT3 signalling in cancer: New and unexpected biological functions. Nat. Rev. Cancer 2014, 14, 736-746. [CrossRef]

31. Siveen, K.S.; Sikka, S.; Surana, R.; Dai, X.; Zhang, J.; Kumar, A.P.; Tan, B.K.; Sethi, G.; Bishayee, A. Targeting the STAT3 signaling pathway in cancer: Role of synthetic and natural inhibitors. Biochim. Biophys. Acta Rev. Cancer 2014, 1845, 136-154. [CrossRef]

32. Kim, M.J.; Lim, J.; Yang, Y.; Lee, M.S.; Lim, J.S. N-myc downstream-regulated gene 2 (NDRG2) suppresses the epithelialmesenchymal transition (EMT) in breast cancer cells via STAT3/Snail signaling. Cancer Lett. 2014, 354, 33-42. [CrossRef]

33. Lee, M.Y.; Shen, M.R. Epithelial-mesenchymal transition in cervical carcinoma. Am. J. Transl. Res. 2012, 4, 1-13.

34. Lee, T.L.; Yeh, J.; Van Waes, C.; Chen, Z. Epigenetic modification of SOCS-1 differentially regulates STAT3 activation in response to interleukin-6 receptor and epidermal growth factor receptor signaling through JAK and/or MEK in head and neck squamous cell carcinomas. Mol. Cancer Ther. 2006, 5, 8-19. [CrossRef] [PubMed]

35. Park, Y.; Shon, S.K.; Kim, A.; Kim, K.I.; Yang, Y.; Cho, D.H.; Lee, M.S.; Lim, J.S. SOCS1 induced by NDRG2 expression negatively regulates STAT3 activation in breast cancer cells. Biochem. Biophys. Res. Commun. 2007, 363, 361-367. [CrossRef]

36. Boerner, P.; Resnick, R.J.; Racker, E. Stimulation of glycolysis and amino acid uptake in NRK-49F cells by transforming growth factor beta and epidermal growth factor. Proc. Natl. Acad. Sci. USA 1985, 82, 1350-1353. [CrossRef]

37. Flier, J.S.; Mueckler, M.M.; Usher, P.; Lodish, H.F. Elevated levels of glucose transport and transporter messenger RNA are induced by ras or src oncogenes. Science 1987, 235, 1492-1495. [CrossRef] [PubMed]

38. Birnbaum, M.J.; Haspel, H.C.; Rosen, O.M. Transformation of rat fibroblasts by FSV rapidly increases glucose transporter gene transcription. Science 1987, 235, 1495-1498. [CrossRef] [PubMed]

39. Hiraki, Y.; Rosen, O.M.; Birnbaum, M.J. Growth factors rapidly induce expression of the glucose transporter gene. J. Biol. Chem. 1988, 263, 13655-13662. [CrossRef]

40. Deng, D.; Xu, C.; Sun, P.; Wu, J.; Yan, C.; Hu, M.; Yan, N. Crystal structure of the human glucose transporter GLUT1. Nature 2014, 510, 121-125. [CrossRef]

41. Ancey, P.B.; Contat, C.; Meylan, E. Glucose transporters in cancer-from tumor cells to the tumor microenvironment. FEBS J. 2018, 285, 2926-2943. [CrossRef]

42. Chan, D.A.; Sutphin, P.D.; Nguyen, P.; Turcotte, S.; Lai, E.W.; Banh, A.; Reynolds, G.E.; Chi, J.T.; Wu, J.; Solow-Cordero, D.E.; et al. Targeting GLUT1 and the Warburg effect in renal cell carcinoma by chemical synthetic lethality. Sci. Transl. Med. 2011, 3, 94ra70. [CrossRef]

43. Amann, T.; Hellerbrand, C. GLUT1 as a therapeutic target in hepatocellular carcinoma. Expert Opin. Ther. Targets 2009, 13, 1411-1427. [CrossRef] [PubMed]

44. Basturk, O.; Singh, R.; Kaygusuz, E.; Balci, S.; Dursun, N.; Culhaci, N.; Adsay, N.V. GLUT-1 expression in pancreatic neoplasia: Implications in pathogenesis, diagnosis, and prognosis. Pancreas 2011, 40, 187-192. [CrossRef]

45. Xu, X.; Li, J.; Sun, X.; Guo, Y.; Chu, D.; Wei, L.; Li, X.; Yang, G.; Liu, X.; Yao, L.; et al. Tumor suppressor NDRG2 inhibits glycolysis and glutaminolysis in colorectal cancer cells by repressing c-Myc expression. Oncotarget 2015, 6, 26161-26176. [CrossRef] [PubMed]

46. Ozawa, N.; Goda, N.; Makino, N.; Yamaguchi, T.; Yoshimura, Y.; Suematsu, M. Leydig cell-derived heme oxygenase-1 regulates apoptosis of premeiotic germ cells in response to stress. J. Clin. Investig. 2002, 109, 457-467. [CrossRef] [PubMed]

47. Kim, S.K.; Yoon, Y.D.; Park, Y.S.; Seo, J.T.; Kim, J.H. Involvement of the Fas-Fas ligand system and active caspase-3 in abnormal apoptosis in human testes with maturation arrest and Sertoli cell-only syndrome. Fertil. Steril. 2007, 87, 547-553. [CrossRef] [PubMed]

48. Li, T.; Hu, J.; He, G.H.; Li, Y.; Zhu, C.C.; Hou, W.G.; Zhang, S.; Li, W.; Zhang, J.S.; Wang, Z.; et al. Up-regulation of NDRG2 through nuclear factor-kappa B is required for Leydig cell apoptosis in both human and murine infertile testes. Biochim. Biophys. Acta Mol. Basis Dis. 2012, 1822, 301-313. [CrossRef]

49. Moreno, R.D.; Lizama, C.; Urzua, N.; Vergara, S.P.; Reyes, J.G. Caspase activation throughout the first wave of spermatogenesis in the rat. Cell Tissue Res. 2006, 325, 533-540. [CrossRef]

50. Yin, Y.; Stahl, B.C.; DeWolf, W.C.; Morgentaler, A. P53 and Fas are sequential mechanisms of testicular germ cell apoptosis. J. Androl. 2002, 23, 64-70. [CrossRef]

51. Hou, W.; Hu, J.; Li, Y.; Zhao, J.; Li, Z.; Liu, X.; Yao, L.; Zhang, Y. Altered expression of NDRG2 in the testes of experimental rat model of cryptorchidism. Urology 2010, 75, 985-991. [CrossRef] [PubMed] 
52. Liu, N.; Wang, L.; Li, X.; Yang, Q.; Liu, X.; Zhang, J.; Wu, Y.; Ji, S.; Zhang, Y.; Yang, A.; et al. N-Myc downstream-regulated gene 2 is involved in p53-mediated apoptosis. Nucleic Acids Res. 2008, 36, 5335-5349. [CrossRef]

53. Vousden, K.H.; Lu, X. Live or let die: The cell's response to p53. Nat. Rev. Cancer 2002, 2, 594-604. [CrossRef] [PubMed]

54. Fridman, J.S.; Lowe, S.W. Control of apoptosis by p53. Oncogene 2003, 22, 9030-9040. [CrossRef] [PubMed]

55. Schmitt, C.A.; Fridman, J.S.; Yang, M.; Baranov, E.; Hoffman, R.M.; Lowe, S.W. Dissecting p53 tumor suppressor functions in vivo. Cancer Cell 2002, 1, 289-298. [CrossRef]

56. Cao, W.; Zhang, J.L.; Feng, D.Y.; Liu, X.W.; Li, Y.; Wang, L.F.; Yao, L.B.; Zhang, H.; Zhang, J. The effect of adenovirusconjugated NDRG2 on p53-mediated apoptosis of hepatocarcinoma cells through attenuation of nucleotide excision repair capacity. Biomaterials 2014, 35, 993-1003. [CrossRef]

57. Troelstra, C.; Landsvater, R.M.; Wiegant, J.; van der Ploeg, M.; Viel, G.; Buys, C.H.; Hoeijmakers, J.H. Localization of the nucleotide excision repair gene ERCC6 to human chromosome 10q11-q21. Genomics 1992, 12, 745-749. [CrossRef]

58. Fink, D.; Aebi, S.; Howell, S.B. The role of DNA mismatch repair in drug resistance. Clin. Cancer Res. Off. J. Am. Assoc. Cancer Res. 1998, 4, 1-6.

59. Sun, Y. E3 ubiquitin ligases as cancer targets and biomarkers. Neoplasia 2006, 8, 645-654. [CrossRef]

60. Wang, S.; Chen, N.; Dong, N.; Lu, L.; Liu, L.; Zhang, L. Adenovirus siMDM2 and NDRG2 Gene Therapy Inhibits Cell Proliferation and Induces Apoptosis of Squamous Cell Carcinoma. Cell Biochem. Biophys. 2015, 73, 513-518. [CrossRef]

61. You, M.H.; Kim, B.M.; Chen, C.H.; Begley, M.J.; Cantley, L.C.; Lee, T.H. Death-associated protein kinase 1 phosphorylates NDRG2 and induces neuronal cell death. Cell Death Differ. 2017, 24, 238-250. [CrossRef]

62. Bialik, S.; Kimchi, A. The death-associated protein kinases: Structure, function, and beyond. Annu. Rev. Biochem. 2006, 75, 189-210. [CrossRef]

63. Chen, H.Y.; Lee, Y.R.; Chen, R.H. The functions and regulations of DAPK in cancer metastasis. Apoptosis Int. J. Program. Cell Death 2014, 19, 364-370. [CrossRef] [PubMed]

64. Michie, A.M.; McCaig, A.M.; Nakagawa, R.; Vukovic, M. Death-associated protein kinase (DAPK) and signal transduction: Regulation in cancer. FEBS J. 2010, 277, 74-80. [CrossRef] [PubMed]

65. Raveh, T.; Droguett, G.; Horwitz, M.S.; DePinho, R.A.; Kimchi, A. DAP kinase activates a p19ARF/p53-mediated apoptotic checkpoint to suppress oncogenic transformation. Nat. Cell Biol. 2001, 3, 1-7. [CrossRef] [PubMed]

66. Martoriati, A.; Doumont, G.; Alcalay, M.; Bellefroid, E.; Pelicci, P.G.; Marine, J.C. Dapk1, encoding an activator of a p19ARF-p53mediated apoptotic checkpoint, is a transcription target of p53. Oncogene 2005, 24, 1461-1466. [CrossRef] [PubMed]

67. Wei, Y.; Yu, S.; Zhang, Y.; Zhao, H.; Xiao, Z.; Yao, L.; Chen, S.; Zhang, J. NDRG2 promotes adriamycin sensitivity through a $\mathrm{Bad} / \mathrm{p} 53$ complex at the mitochondria in breast cancer. Oncotarget 2017, 8, 29038-29047. [CrossRef] [PubMed]

68. Cui, Y.; Shen, G.; Ma, L.; Lv, Q. Overexpression of NDRG2 promotes the therapeutic effect of pazopanib on ovarian cancer. J. Recept. Signal Transduct. 2020, 1-7. [CrossRef]

69. Park, S.; Oh, S.S.; Lee, K.W.; Lee, Y.K.; Kim, N.Y.; Kim, J.H.; Yoo, J.; Kim, K.D. NDRG2 contributes to cisplatin sensitivity through modulation of BAK-to-Mcl-1 ratio. Cell Death Dis. 2018, 9, 30. [CrossRef]

70. Park, S.; Han, H.T.; Oh, S.S.; Kim, D.H.; Jeong, J.W.; Lee, K.W.; Kim, M.; Lim, J.S.; Cho, Y.Y.; Hwangbo, C.; et al. NDRG2 Sensitizes Myeloid Leukemia to Arsenic Trioxide via GSK3beta-NDRG2-PP2A Complex Formation. Cells 2019, 8, 495. [CrossRef]

71. Inoshita, S.; Takeda, K.; Hatai, T.; Terada, Y.; Sano, M.; Hata, J.; Umezawa, A.; Ichijo, H. Phosphorylation and inactivation of myeloid cell leukemia 1 by JNK in response to oxidative stress. J. Biol. Chem. 2002, 277, 43730-43734. [CrossRef]

72. Peidis, P.; Papadakis, A.I.; Muaddi, H.; Richard, S.; Koromilas, A.E. Doxorubicin bypasses the cytoprotective effects of eIF2alpha phosphorylation and promotes PKR-mediated cell death. Cell Death Differ. 2011, 18, 145-154. [CrossRef]

73. Donnelly, N.; Gorman, A.M.; Gupta, S.; Samali, A. The eIF2alpha kinases: Their structures and functions. Cell. Mol. Life Sci. CMLS 2013, 70, 3493-3511. [CrossRef]

74. Drummond, G.R.; Selemidis, S.; Griendling, K.K.; Sobey, C.G. Combating oxidative stress in vascular disease: NADPH oxidases as therapeutic targets. Nat. Rev. Drug Discov. 2011, 10, 453-471. [CrossRef] [PubMed]

75. Pyo, C.W.; Lee, S.H.; Choi, S.Y. Oxidative stress induces PKR-dependent apoptosis via IFN-gamma activation signaling in Jurkat T cells. Biochem. Biophys. Res. Commun. 2008, 377, 1001-1006. [CrossRef] [PubMed]

76. Jing, Y.; Dai, J.; Chalmers-Redman, R.M.; Tatton, W.G.; Waxman, S. Arsenic trioxide selectively induces acute promyelocytic leukemia cell apoptosis via a hydrogen peroxide-dependent pathway. Blood 1999, 94, 2102-2111. [CrossRef]

77. Morishita, K.; Nakahata, S.; Ichikawa, T. Pathophysiological significance of N-myc downstream-regulated gene 2 in cancer development through protein phosphatase 2A phosphorylation regulation. Cancer Sci. 2021, 112, 22-30. [CrossRef] [PubMed]

78. Sprick, J.D.; Mallet, R.T.; Przyklenk, K.; Rickards, C.A. Ischaemic and hypoxic conditioning: Potential for protection of vital organs. Exp. Physiol. 2019, 104, 278-294. [CrossRef]

79. Cadenas, S. ROS and redox signaling in myocardial ischemia-reperfusion injury and cardioprotection. Free Radic. Biol. Med. 2018, 117, 76-89. [CrossRef]

80. Busl, K.M.; Greer, D.M. Hypoxic-ischemic brain injury: Pathophysiology, neuropathology and mechanisms. NeuroRehabilitation 2010, 26, 5-13. [CrossRef]

81. Vaupel, P.; Harrison, L. Tumor hypoxia: Causative factors, compensatory mechanisms, and cellular response. Oncologist 2004, 9 , 4-9. [CrossRef] 
82. Terry, S.; Buart, S.; Chouaib, S. Hypoxic Stress-Induced Tumor and Immune Plasticity, Suppression, and Impact on Tumor Heterogeneity. Front. Immunol. 2017, 8, 1625. [CrossRef] [PubMed]

83. Bhandari, V.; Hoey, C.; Liu, L.Y.; Lalonde, E.; Ray, J.; Livingstone, J.; Lesurf, R.; Shiah, Y.J.; Vujcic, T.; Huang, X.; et al. Molecular landmarks of tumor hypoxia across cancer types. Nat. Genet. 2019, 51, 308-318. [CrossRef] [PubMed]

84. Semenza, G.L. Oxygen sensing, hypoxia-inducible factors, and disease pathophysiology. Annu. Rev. Pathol. 2014, 9, 47-71. [CrossRef]

85. Semenza, G.L. HIF-1 and mechanisms of hypoxia sensing. Curr. Opin. Cell Biol. 2001, 13, 167-171. [CrossRef]

86. Yang, G.; Shi, R.; Zhang, Q. Hypoxia and Oxygen-Sensing Signaling in Gene Regulation and Cancer Progression. Int. J. Mol. Sci. 2020, 21, 8162. [CrossRef]

87. Wang, L.; Liu, N.; Yao, L.; Li, F.; Zhang, J.; Deng, Y.; Liu, J.; Ji, S.; Yang, A.; Han, H.; et al. NDRG2 is a new HIF-1 target gene necessary for hypoxia-induced apoptosis in A549 cells. Cell. Physiol. Biochem. Int. J. Exp. Cell. Physiol. Biochem. Pharmacol. 2008, 21, 239-250. [CrossRef] [PubMed]

88. Zhang, X.; Zhang, C.; Wang, N.; Li, Y.; Zhang, D.; Li, Q. MicroRNA-486 Alleviates Hypoxia-Induced Damage in H9c2 Cells by Targeting NDRG2 to Inactivate JNK/C-Jun and NF-kappaB Signaling Pathways. Cell. Physiol. Biochem. Int. J. Exp. Cell. Physiol. Biochem. Pharmacol. 2018, 48, 2483-2492. [CrossRef] [PubMed]

89. Guo, Y.J.; Liu, J.X.; Guan, Y.W. Hypoxia induced upregulation of miR-301a/b contributes to increased cell autophagy and viability of prostate cancer cells by targeting NDRG2. Eur. Rev. Med. Pharmacol. Sci. 2016, 20, 101-108.

90. Wang, W.; Liu, M.; Guan, Y.; Wu, Q. Hypoxia-Responsive Mir-301a and Mir-301b Promote Radioresistance of Prostate Cancer Cells via Downregulating NDRG2. Med. Sci. Monit. Int. Med. J. Exp. Clin. Res. 2016, 22, 2126-2132. [CrossRef]

91. Li, Y.; Xu, N.; Cai, L.; Gao, Z.; Shen, L.; Zhang, Q.; Hou, W.; Zhong, H.; Wang, Q.; Xiong, L. NDRG2 is a novel p53-associated regulator of apoptosis in C6-originated astrocytes exposed to oxygen-glucose deprivation. PLoS ONE 2013, 8, e57130. [CrossRef]

92. Kim, H.S.; Kim, M.J.; Lim, J.; Yang, Y.; Lee, M.S.; Lim, J.S. NDRG2 overexpression enhances glucose deprivation-mediated apoptosis in breast cancer cells via inhibition of the LKB1-AMPK pathway. Genes Cancer 2014, 5, 175-185. [CrossRef] [PubMed]

93. Meley, D.; Bauvy, C.; Houben-Weerts, J.H.; Dubbelhuis, P.F.; Helmond, M.T.; Codogno, P.; Meijer, A.J. AMP-activated protein kinase and the regulation of autophagic proteolysis. J. Biol. Chem. 2006, 281, 34870-34879. [CrossRef]

94. Egan, D.F.; Shackelford, D.B.; Mihaylova, M.M.; Gelino, S.; Kohnz, R.A.; Mair, W.; Vasquez, D.S.; Joshi, A.; Gwinn, D.M.; Taylor, R.; et al. Phosphorylation of ULK1 (hATG1) by AMP-activated protein kinase connects energy sensing to mitophagy. Science 2011, 331, 456-461. [CrossRef] [PubMed]

95. Kim, J.; Kundu, M.; Viollet, B.; Guan, K.L. AMPK and mTOR regulate autophagy through direct phosphorylation of Ulk1. Nat. Cell Biol. 2011, 13, 132-141. [CrossRef]

96. Maiuri, M.C.; Zalckvar, E.; Kimchi, A.; Kroemer, G. Self-eating and self-killing: Crosstalk between autophagy and apoptosis. Nat. Rev. Mol. Cell Biol. 2007, 8, 741-752. [CrossRef] [PubMed] 